\title{
The efficiency of dental volumetric tomography-derived radiomorphometric indices for diagnosing osteoporosis
}

\section{Osteoporoz Teşhisinde Dental Volümetrik Tomografiden Üretilen Radyomorfometrik İndekslerin Etkinliği}

\author{
Burcu EVLICE, Ufuk TATLI, Tunay SARPEL, Haluk ÖZTUNÇ ${ }^{4}$ \\ 1 Çukurova University Faculty of Dentistry, Department of Oral and Maxillofacial Radiology, Adana, Turkey \\ 2 Çukurova University Faculty of Dentistry, Department of Oral and Maxillofacial Surgery, Adana, Turkey \\ 3 Çukurova University Faculty of Medicine, Physical Medicine and Rehabilitation, Adana, Turkey \\ 4 Kyrenia University Faculty of Dentistry, Department of Oral and Maxillofacial Radiology, Kyrenia, Turkish Republic of Northern Cyprus
}

Yazışma Adresi

Correspondence Address

\section{Burcu EVLICE}

Çukurova University Faculty of Dentistry,Department of Oral and Maxillofacial Radiology

, Adana, Turkey

burcukelesevlice@gmail.com

Geliş tarihi / Received : Kas 11, 2020 Kabul tarihi / Accepted : Ara 03, 2020 Elektronik yayın tarihi : Eyl 01,2021 Online published

Cite this article as:

Bu makalede yapılacak atıf:

Evlice B, Tatlı U,

Sarpel T, Öztunç H

The efficiency of dental

volumetric tomography-

derived radiomorphometric

indices for diagnosing

osteoporosis

Akd Med J / 2021; 7(3):350-354

Burcu EVLICE

ORCID ID: 0000-0003-3384-0092 Ufuk TATLI

ORCID ID: 0000-0003-1580-9980

Tunay SARPEL

ORCID ID: 0000-0002-6519-9757

Haluk ÖZTUNÇ

ORCID ID: 0000-0001-8321-1599

\section{ABSTRACT \\ Objective:}

The aim of the present study was to assess the efficiency of dental volumetric tomography (DVT) radiomorphometric indices to detect osteoporosis in post-menopausal females, compare them with the osteopenic and normal groups and to assess the correlations of the DVT findings with the bone mineral density values measured by Dual energy X-ray absorptiometry (DEXA).

\section{Method:}

This study consisted of 120 post-menopausal females, with age ranging from 48 to 67 years. Based on their DEXA results, they were classified into osteoporotic, osteopenic and normal groups. Dental volumetric tomographical radiomorphometric indices were measured and compared with DEXA parameters of the patients.

\section{Results:}

Dental volumetric cortical thickness (DVT-CT) displayed significant differences between the groups and decreased in osteoporotic individuals. The mean values of dental volumetric tomographic mandibular index superior (DVT-MIS) and dental volumetric tomographic mandibular index inferior (DVT-MII) for osteoporosis group was significantly lower than osteopenic and normal groups. In both normal and osteopenic patient groups, there were significant correlations between the spine $t$ score and DVT-MIS $(\mathrm{p}<0.05)$. Osteoporotic patient group displayed statistically significant relationship between spine $t$ score and DVT-CT.

\section{Conclusions:}

DVT-CT parameter which was found to be associated with the spine DEXA measurements, can be used to diagnose osteoporotic patients. Dental volumetric tomography can help clinicians as a useful tool to evaluate osteoporotic patients.

Keywords: Dental volumetric tomography, Dual energy x-ray absorptiometry, Osteoporosis.

ÖZ

Amaç:

Bu çalışmanın amacı post-menapozal hastalarda osteoporozu saptamak için dental volumetrik tomografi (DVT) radyomorfometrik indekslerinin etkinliğini değerlendirmek, bunları osteopenik ve normal gruplarla karşılaştırmak ve çift enerjili X-1̧̧ını absorpsiyometrisi (DEXA) ile ölçülen kemik mineral yoğunluğu değerleri ile DVT bulgularının korelasyonlarını değerlendirmektir. 


\section{Yöntem:}

$\mathrm{Bu}$ çalışmaya, yaşları 48- 67 arasında değişen 120 post-menopozal hasta dahil edildi. Çalışma grubu DEXA sonuçlarına göre osteoporotik, osteopenik ve normal olarak sinıflandirıldı. Dental volumetrik tomografik radyomorfometrik indeksler ölçüldü ve hastaların DEXA parametreleri ile karşılaştırıldı.

\section{Bulgular:}

Dental volumetrik kortikal kalınlık (DVT-KK) gruplar arasında önemli farklilıklar gösterdi ve osteoporotik bireylerde azald1. Osteoporoz grubunda dental volümetrik tomografik mandibular indeks superior (DVT-MIS) ve dental volümetrik tomografik mandibular indeks inferior (DVT-MII) ortalama değerleri, osteopenik ve normal gruplara göre anlamlı olarak düşüktü. Hem normal hem de osteopenik grupta, omurga $t$ skoru ile DVT-MIS arasında anlamlı korelasyon vardı (p $<0.05$ ). Osteoporotik hasta grubu, omurga t skoru ile DVT-KK arasında istatistiksel olarak anlamlı ilişki gösterdi.

\section{Sonuç:}

Omurga DEXA ölçümleri ile ilişkili olduğu bulunan DVT-KK parametresi, osteoporotik hastaları teşhis etmek için kullanılabilir. Dental volümetrik tomografi, klinisyenlere osteoporotik hastaları değerlendirmek için yararlı bir araç olarak yardımcı olabilir.

Anahtar Sözcükler: Çift enerjili X-ışını absorpsiyometrisi, Dental volumetrik tomografi, Osteoporoz.

\section{Introduction}

Bone Mineral Density (BMD) in the scope of densitometer is defined as bone tissue mass that includes both bone and bone marrow components. Before the development of bone densitometers, bone density was measured using X-ray by comparing the radiance of the skeleton with other surrounding tissues (1). Osteoporosis, which causes low bone quality, is a chronic, systemic metabolic bone disease that affects people's quality of life. Osteoporosis-related changes in jawbones are not different from the other bones of the body (2).

Dual energy X-ray absorptiometry (DEXA) is commonly performed for measuring BMD (3). Although DEXA has been considered the gold standard for this purpose, it has some disadvantages, such as large equipment size, high cost, and difficulty in interpreting results, which limit its utility (4). In DEXA, BMD, z-scores and t-scores are reported. Per standard protocol, a t-score between -1.0 and -2.4 yields a diagnosis of osteopenia; a t-score below -2.5 corresponds to a diagnosis of osteoporosis $(5,6)$.

Dental volumetric tomography (DVT), which is also known as cone beam computed tomography (CBCT), became a useful tool for oral and maxillofacial imaging, providing clinicians access to excellent image quality and greater diagnostic accuracy and sensitivity (7-9). CBCT allows images to be acquired using a low dose of radiation, shorter patient examination time and lower costs than conventional computerized tomography $(\mathrm{CT})$, which makes its routine use practicable for oral and maxillofacial imaging and surgical procedures (7-9).

The primary aim of the present study was to assess the efficiency of radiomorphometric indices to detect osteoporosis in post-menopausal females and compare the results with the osteopenic and normal groups. The second aim was to assess the correlations of the CBCT findings with the bone mineral density values measured by DEXA.

\section{Materials and Methods}

This study was approved by Non-Interventional Clinical Research Ethics Committee of Cukurova University Faculty of Medicine (approval number: 30.06.2009-7). The participants of the study were 120 post-menopausal women (ages range between 48 and 67; average: $59.9 \pm 5.33)$ whose BMD measurements were performed using DEXA (Hologic Explorer QDR, Hologic Inc., Bedford, MA 01730, USA) device in the same month. The participants were divided into three groups as normal group $(n=40)$, osteopenia group $(n=40)$ and osteoporosis group $(n=40)$ according to the WHO criteria. All procedures performed in studies involving human participants were in accordance with the ethical standards of the institutional research committee and with the 1964 Helsinki declaration and its later amendments or comparable ethical standards. All the participants signed the informed consent form. The exclusion criteria were as follows: individuals with metabolic diseases (hyper / hypoparathyroidism, diabetes mellitus, osteomalacia, thyrotoxicosis and renal disease), hormone replacement treatment, early menopause, medication that can affect BMD, chronic alcoholism and long-term partial or total edentulism without prosthetic rehabilitation.

Each patient's BMD value, t-score and z-score were measured in terms of L1-L4 spine from the lumbar area, femur neck of the left femoral area and total hip $(\mathrm{g} / \mathrm{cm} 2)$ with DEXA method.

The participants of the study were referred from Department of Physical Medicine and Rehabilitation, Faculty of Medicine, Cukurova University to Department of Oral and Maxillofacial Radiology, Faculty of Dentistry in order to evaluate jaw-bones by $\mathrm{CBCT}$ scanning. Images were obtained from the institution's CBCT device (Iluma CBCT Scanner, imtec imaging, LLC, Ardmore, OK, USA) at $120 \mathrm{kV}, 3.8 \mathrm{~mA}, 20$ seconds, FOV of $24.4 \times 19.5 \mathrm{~cm}$ and the voxel size was $0.3 \mathrm{~mm}^{3}$.

Two oral and maxillofacial radiologists performed the linear and radiomorphometric measurements on a 22-inch LG Flatron monitor (LG, Seoul, Korea) set at a screen resolution of $1440 \times 900$ pixel screen resolution and 32-bit color depth. Each image was evaluated separately in a random order using the CBCT device software and enhancement tools of the imaging system. Images were re-evaluated 2 weeks after the initial evaluation to permit calculation of the intraclass correlation coefficient (ICC) with a confidence interval (CI) of $95 \%$.

\section{Radiomorphometric Measurements}

The measurements were performed on coronal CBCT images by modifying Ledgerton's (10) classification on the panoram- 
ic images (11). Coronal sections were evaluated in the posteroanterior direction. The images with the inferior and superior borders of foramen mentale (FM) and inferior border of cortical bone were enrolled in the study.

A- Dental Volumetric Tomographic Mandibular Index (DVT-MI)

DVT-MI Superior (DVTMIS): The ratio of the distance between the line tangential to the inferior border of cortical bone in the coronal sections and the line parallel to this line and tangential to the superior border of FM were measured on the right and left sides, and the mean values were calculated (Figure 1).

DVT-MI Inferior (DVTMII): The ratio of the distance between the line tangential to the inferior border of cortical bone in the coronal sections and the line parallel to this line and tangential to the inferior level of FM were measured on the right and left sides, and the mean values were calculated (Figure 1).

B- Dental Volumetric Tomographical Cortical Thickness (DVT-CT): The distance between the line tangential to the inferior and superior border of cortical bone in the coronal sections was measured on the right and the left sides and the mean values were calculated (Figure 1).

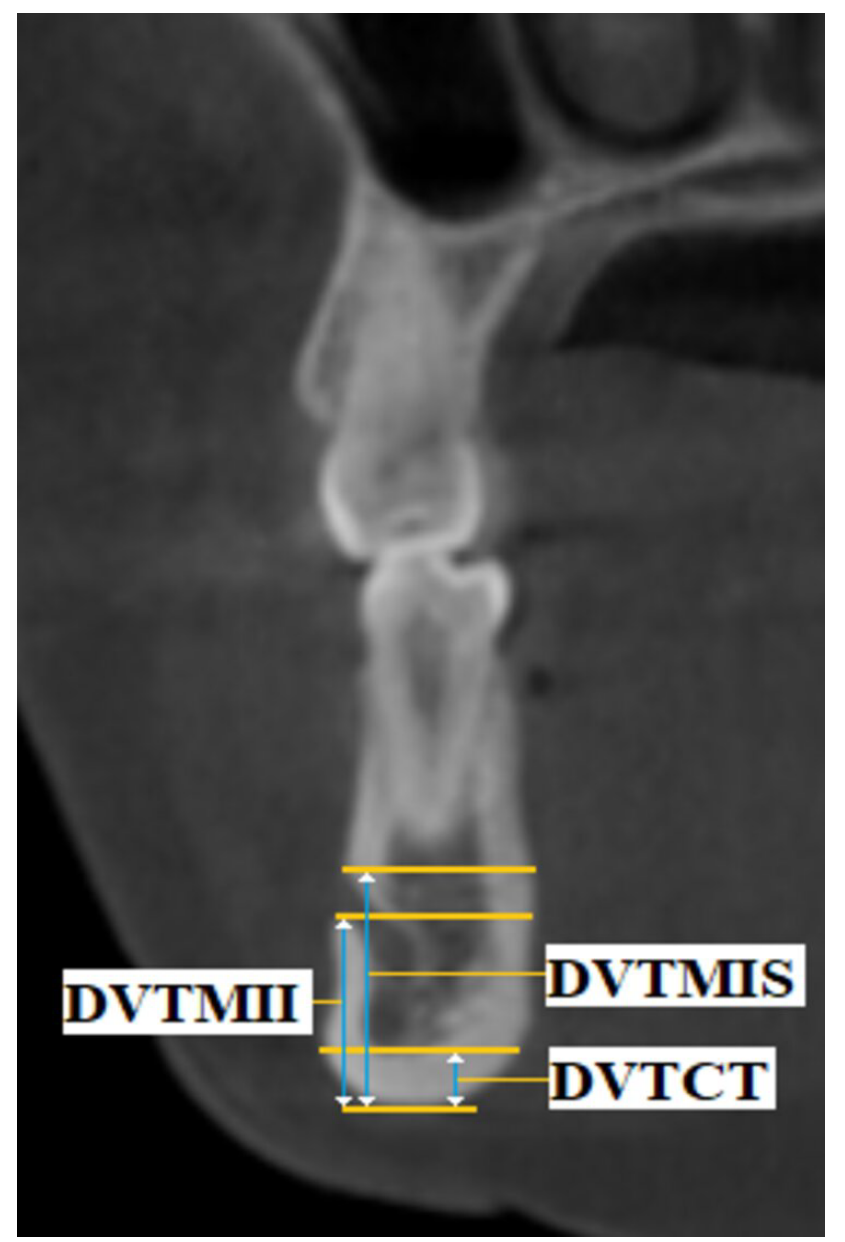

Figure I: Dental volumetric tomographical radiomorphometric measurements on the cross-sectional images of Iluma-DVT scanner.

\section{Statistical Analyses}

Statistical analyses were conducted using 20.0 version of SPSS (Statistical Package for Social Science) program. Coefficient of variation $(\mathrm{CV})$ and intraclass correlation coefficient (ICC) were used for intra-examiner and inter-examiner reliability. The suitability of data for normal distribution was evaluated by histogram and Q-Q plots and Shapiro-Wilk test. Since data displayed normal distribution, they were analysed using descriptive statistics, one-way variance analysis (ANOVA), and Pearson Correlation Analysis. Statistical significance was taken 0.05 in all tests.

\section{Results}

For all measurements, $\mathrm{CV}$ values ranged between $4.1 \%$ and $5.1 \%$, while ICC values ranged between 0.94 and 0.95 showing excellent agreement.

A statistically significant difference was found between the groups for DVT-CT, DVT-MIS and DVT-MII parameters. The mean values for osteoporosis group was found significantly lower compared to other two groups for DVT-MIS and DVT-MII parameters. No significant difference was found between the normal and osteopenia groups for DVT-MIS and DVT-MII ( $>>0.05)$ (Table I).

Table I: Comparison of DVT parameters of all the participants.

\begin{tabular}{|c|c|c|c|c|c|}
\hline & & Normal & Osteopenia & Osteoporosis & $\mathbf{p}^{*}$ \\
\hline Mean DVT- & DVTMIS & $0.268^{*}$ & $0.258^{2}$ & $0.238^{8}$ & $<0.001$ \\
\hline \multirow[t]{2}{*}{ Indices } & DVTMII & $0.328^{*}$ & $0.313^{*}$ & $0.284^{b}$ & $<0.001$ \\
\hline & DVTCT & $4.0^{\mathrm{s}}$ & $3.8^{b}$ & $3.2^{t}$ & $<0.001$ \\
\hline
\end{tabular}

\section{DVTMIS:}

Dental volumetric tomographic mandibular index superior DVTMII:

Dental volumetric tomographic mandibular index inferior DVTCT: Dental volumetric tomographical cortical thickness a,a,b: No difference between two groups, the third group is different from others a,b,c: Three groups different from each other *One-way variance analysis (ANOVA)

The spine t-score was the only DEXA parameter that correlated with the DVT-indices in all three groups. In both normal and osteopenic patient groups, there was a statistically significant relationship between the spine $\mathrm{t}$ score and DVT-MIS $(\mathrm{p}<0.05)$. Osteoporotic patient group showed statistically significant relationship between spine t- score and DVT-CT. Statistically significant relationships were observed between DEXA results and DVT measurements for the groups (Table II). 
Table II: Comparison of DVT radiomorphometric measurements to DEXA results of the groups.

\begin{tabular}{|c|c|c|c|c|c|c|c|c|c|c|}
\hline & & \multicolumn{3}{|c|}{ OSTEOPOROSIS GROUP } & \multicolumn{3}{|c|}{ OSTEOPENTA GROUP } & \multicolumn{3}{|c|}{ NORMAL GROUP } \\
\hline & & DNTCT & DVTMIII & VTMMS & DVTCT & DVTMaI & DVTMIS & DVTCT & DVTMII & DVTMIS \\
\hline \multirow{2}{*}{$\begin{array}{l}\text { Spine } \\
\text { t scere }\end{array}$} & Pearcon $\mathbb{R}$ & $0.34 *$ & -0.15 & -0.15 & -0.108 & & & 0.111 & -0.15 & $0.33^{\circ}$ \\
\hline & $\mathrm{p}^{*}$ & 0.033 & 0.354 & 0.354 & 0.508 & 0.701 & 0.008 & 0.497 & 0.354 & 0.040 \\
\hline \multirow{2}{*}{$\begin{array}{l}\text { Spise } \\
\text { z scare }\end{array}$} & Pearzon $\mathbf{R}$ & 0.29 & -0.011 & 0.010 & 0.164 & -0.053 & 0.119 & 0.183 & 0.026 & 0.20 \\
\hline & $\mathbf{p}^{*}$ & & & 0.949 & & & & & 875 & $\begin{array}{r}0.227 \\
40\end{array}$ \\
\hline \multirow{3}{*}{$\begin{array}{l}\text { Spine } \\
\text { BMD }\end{array}$} & Pearcon $\mathbf{R}$ & 0.29 & -0.015 & -0.069 & 0.196 & 0.045 & 0.303 & 0.140 & 0.141 & 0.119 \\
\hline & $\mathrm{p}^{*}$ & 0.066 & 0.926 & 0.674 & 0.226 & 0.784 & 0.058 & 0.389 & 0.386 & 0.463 \\
\hline & $\mathrm{x}$ & 40 & 40 & 40 & 40 & 40 & 40 & 40 & 40 & 40 \\
\hline \multirow{3}{*}{$\begin{array}{l}\text { Femur } \\
\text { Neck } \\
\text { t scoore }\end{array}$} & Pearcon $\mathbb{R}$ & 0.146 & 0.141 & 0.140 & 0.132 & -0.062 & -0.113 & -0.131 & 0.285 & 0.132 \\
\hline & $\mathbf{P}^{*}$ & 0.370 & 0.386 & 0.369 & 0.417 & 0.702 & 0.488 & 0.421 & 0.074 & 0.417 \\
\hline & $\mathbf{x}$ & 40 & 40 & 40 & 40 & 40 & 40 & 40 & 40 & 40 \\
\hline \multirow{3}{*}{$\begin{array}{l}\text { Fewur } \\
\text { Neck } \\
\text { z score }\end{array}$} & Pearcon $\mathbb{R}$ & 0.22 & 0.09 & -0.090 & 0.125 & 0.196 & -0.15 & -0.226 & 0.285 & 0.09 \\
\hline & $\nabla^{*}$ & 0.168 & 0.566 & 0.590 & 0.442 & 0.226 & 0.354 & 0.160 & 0.074 & 0.566 \\
\hline & s & 40 & 40 & 40 & 40 & 40 & 40 & 40 & 40 & 40 \\
\hline \multirow{3}{*}{$\begin{array}{l}\text { Femur } \\
\text { Neck } \\
\text { BMD }\end{array}$} & Pearoon $\mathbb{R}$ & 0.09 & 0.026 & -0.022 & -0.057 & 0.023 & -0.286 & 0.146 & 0.141 & 0.29 \\
\hline & & 0.593 & 0.875 & 0.894 & 0.728 & 0.887 & 0.073 & 0.370 & 0.386 & 0.071 \\
\hline & s & 40 & 40 & 40 & 40 & 40 & 40 & 40 & 40 & 40 \\
\hline \multirow{2}{*}{$\begin{array}{l}\text { Toual } \\
\text { Hip } \\
\text { t score }\end{array}$} & & 0.141 & -0.226 & -0.113 & -0.106 & 0.069 & 0.285 & 0.132 & -0.131 & 0.119 \\
\hline & $\begin{array}{l}\text { Peat } \\
p^{2}\end{array}$ & $\begin{array}{r}0.386 \\
40\end{array}$ & $\begin{array}{r}0.160 \\
40\end{array}$ & $\begin{array}{r}0.488 \\
40\end{array}$ & 0.515 & 0.673 & 0.074 & 0.417 & 0.421 & 0.463 \\
\hline \multirow{3}{*}{$\begin{array}{l}\text { Total } \\
\text { Hip } \\
\text { z score }\end{array}$} & Pearcoun $\bar{K}$ & 0.29 & -0.108 & -0286 & 0.120 & -0.205 & -0.15 & 0.140 & 0.303 & 029 \\
\hline & $D^{\circ}$ & 0.074 & 0.508 & 0.073 & 0.461 & 0.204 & 0.354 & 0.389 & 0.058 & 0.071 \\
\hline & $\frac{p}{\mathrm{p}}$ & 40 & 40 & 40 & 40 & 40 & 40 & 40 & 40 & 40 \\
\hline \multirow{3}{*}{$\begin{array}{l}\text { Total } \\
\text { Bip } \\
\text { BMD }\end{array}$} & Pearcoun $\mathbb{R}$ & 0.24 & 0.146 & 0.164 & 0.065 & 0.006 & 0.09 & -0.113 & -0.222 & -0.088 \\
\hline & & 0.143 & 0.370 & 0.311 & 0.690 & 0.968 & 0.566 & 0.488 & 0.168 & 0.591 \\
\hline & $\Delta$ & 40 & 40 & 40 & 40 & 40 & 40 & 40 & 40 & 4 \\
\hline
\end{tabular}

BMD: Bone mineral density; DVTMIS: dental volumetric tomographic mandibular index superior; DVTMII: dental volumetric tomographic mandibular index inferior; DVTCT: dental volumetric tomographical cortical thickness.

Significant differences were indicated with the $\bullet$.

* Pearson correlation, two-tailed, $\mathrm{p}<0.05$.

\section{Discussion}

Some of the methods that measure bone density in dental practices include quantitative CT (12), DEXA (13), measurement of HU values from CT (14), degree of density measurement conducted on the conventional radiographic methods and digital radiomorphometric analyses $(15,16)$. These above-mentioned methods also enable to diagnose the present metabolic bone diseases.

Mental index (MI) is the mandibular cortical thickness in the foramen mentale region defined by Ledgerton et al. (17) Panoramic mandibular index inferior (PMII) is the ratio of the distance of the inferior mandible border cortical thickness to the inferior border of foramen mentale (10). According to Wical and Swoop (18) inferior and superior mandibular borders and foramen mentale are the anatomic guide points that could be taken as references. Several studies have investigated the relationship between panoramic radiomorphometric indices and skeletal bone mineral density. Panoramic indices were reported to be useful in the diagnosis of osteopenia and osteoporosis (16-18). Cortical thickness and porosity rating measured on panoramic radiographs were considered to be a radiologically useful method in identifying individuals with systemic osteoporosis risk (19).

Various studies showed that the radiomorphometric indices can also be performed on CBCT images. Kayipmaz et al. (20) evaluated the osteoporotic mandibular changes related type 2 diabetes mellitus by performing radiomorphometric measurements with CBCT. Koh and Kim (11) performed measurements on CBCT images of post-menopausal osteoporotic patients by modifying $\mathrm{CT}$ indices and indicated that
DVT-MIS and DVT-MII parameters could be used in diagnosing osteoporotic women. In their study carried out using the same approach, Katsumata et al. (21) emphasized that CBCT devices could be more effective in identifying bone density by predisposing the reduction of the radiation spread. CBCT was found as a useful tool for screening of low BMD in post-menopausal women (22). Therefore, the authors used CBCT images of post-menopausal patients to perform mandibular index measurements in the present study. It was aimed to assess the efficiency of radiomorphometric indices derived from CBCT to detect osteoporosis in post-menopausal females and compare the results with the osteopenic and normal groups.

DVT-MIS and DVT-MII measurement mean scores did not show any significant differences between normal and osteopenia groups, but the osteoporosis group displayed significant difference compared to the other two groups $(p<0.001)$. In their CBCT study, Koh and Kim (11) also found that there were significant differences between normal group and osteoporosis patients for DVT-MIS and DVT-MII parameters. Our findings are consistent with Kim and Koh.

DVT-CT measurement was found to be correlated with the spine t-score in the osteoporosis group. Also, DVT-CT measurement revealed significant differences between the three groups and was found to be decreased in the osteoporosis group when compared to the other two groups. This finding suggests that DVT-CT measurement can be a useful tool to diagnose osteoporosis. The risk of osteoporosis should be considered in radiological examinations of women in the post-menopausal period. With the widespread use of CBCT devices, further studies should be conducted to identify radiological signs of osteoporosis in the mandible using $\mathrm{CBCT}$ databases.

\section{Conclusion}

In conclusion, DVT-CT parameter which was found to be associated with the spine DEXA measurements, can be used to diagnose osteoporotic patients. CBCT scans can help clinicians as a useful tool to evaluate osteoporotic patients. Clinicians should consider the effect of osteoporosis on jaw bones during dental treatments such as prosthetic rehabilitation with dental implants, orthodontic treatments and surgical interventions.

\section{Acknowledgement}

The present study was extracted from Dr Burcu Evlice's doctoral thesis. The authors are grateful to Dr Sibel Başaran and Dr Pembe Hare Yiğitoğlu for referring patients from Cukurova University Balcalı Hospital's Clinic of Physical Medicine and Rehabilitation.

Ethics Committee Approval: All procedures performed in studies involving human participants were in accordance with the ethical standards of the institutional research committee (approval number: 30.06.2009-7) and with the 1964 Helsinki declaration and its later amendments or comparable ethical standards. 
Informed Consent: All the participants'rights were protected and written informed consents were obtained before the procedures according to the Helsinki Declaration.

Author Contributions: Concept - B.E., H.Ö.; Design B.E., H.Ö.; Supervision - H.Ö., T.S.; Resources - B.E., T.S.; Materials - B.E., T.S.; Data Collection and/or Processing B.E., T.S., U.T.,H.Ö.; Analysis and/ or Interpretation - B.E., U.T.; Literature Search - B.E., U.T.; Writing Manuscript B.E, U.T.; Critical Review - T.S., H.Ö.

Conflict of Interest: BE, UT, TS and HÖ declare that they have no conflict of interest.

Financial Disclosure: This project was supported by Cukurova University Scientific Research Projects Coordination Unit as project no. "DHF2012D3". The authors received no financial support for the authorship and, publication of this article.

\section{References}

1- Looker AC, Orwoll ES, Johnston CC Jr, Lindsay RL, Wahner HW, Dunn WL et al. Prevalance of low femoral bone density in older U.S. adults from NHANES III. J Bone Miner Res 1997;12(11):1761-68.

2- Beikler T, Flemmig. TF Implants in the medically compromised patient. Crit Rev Oral Biol Med 2003;14(4):305-16.

3- Adams J.E. Dual-energy X-ray absorptiometry Grampp S. (Ed.), Radiology of Osteoporosis, Berlin, Heidelberg, Springer, 2013:87-100.

4- Winzenberg T, Jones G. Dual energy X-ray absorptiome try. Austral Fam Physician 2011;40:43-4.

5- World Health Organization. Assessment of fracture risk and its application to screening for postmenopausal osteoporosis. Report of a WHO study group World Health Organ Tech Rep Ser, 1994:1-129.

6- Maghraoui A. El, Roux C. DXA scanning in clinical practice Quart J Med 2008;101:605-17.

7- Gaia BF, Sales MAO, Perrella A, Fenyo-Pereira M, Cavalcanti MGP. Comparison between cone-beam and multislice computed tomography for identification of simulated bone lesions. Braz Oral Res

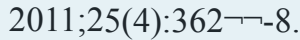

8- Guerrero ME, Jacobs R, Loubele M, Schutyser F, Suetens P, van Steenberghe D. State-of-the-art on cone beam CT imaging for preoperative planning of implant placement. Clin Oral Investig 2006;10(1):1-7.

9- Scarfe WC, Farman AG, Sukovic P. Clinical applications of cone-beam computed tomography in dental practice. $\mathrm{J}$ Can Dent Assoc 2006;72(1):75-80.

10- Ledgerton D, Horner K, Devlin H, Worthington H. Panoramic mandibular index as a radiomorphometric tool An assessment of precision. Dentomaxillofac Radiol
1997;26(2):95-100.

11- Koh KJ, Kim KA. Utility of the computed tomography indices on cone beam computed tomography images in the diagnosis of osteoporosis in women. Imaging Science in Dentistry 2011;41:101-6.

12- Yoo S, Yin FF. Dosimetric feasibility of cone-beam CT-based treatment planning compared to CT-based treatment planning. Int J Radiat Oncol Biol Phys 2006;66(5):1553-61.

13- Lindh C, Petersson A, Klinge B, Nilsson M. Trabecular bone volume and bone mineral density in the mandible. Dentomaxillofac Radiol 1997;26:101-6.

14- Pouilles JM, Tremollieres F, Todorovsky N, Ribot C. Precision and sensitivity of dual-energy $\mathrm{X}$-ray absorpti ometry in spinal osteoporosis. J Bone Miner Res 1991;6:997-1002.

15- Benson BW, Prihoda TJ, Glass BJ. Variations in adult cortical bone mass as measured by a panoramic mandib ular index. Oral Surg Oral Med Oral Pathol 1991;71(3):349-56.

16- Klemetti E, Kolmakov S, Kröger H. Pantomography in assessment of the osteoporosis risk group. Scand J Dent Res 1994;102:68-72.

17- Ledgerton D, Horner K, Devlin H, Worthington H. Radiomorphometric indices of the mandible in a British female population. Dentomaxillofac Radiol 1999;28:173-81.

18- Wical KE, Swoope CC. Studies of residual ridge resorp tion I. Use of panoramic radiographs for evaluation and classification of mandibular resorption. J Prosthet Dent 1974;32(1):7-12.

19- Ishii K, Taguchi A, Nakamoto T, Ohtsuka M, Sutthipra paporn P, Tsuda M. Diagnostic efficacy of alveolar bone loss of the mandible for identifying postmenopausal women with femoral osteoporosis. Dentomaxillofac Radiol 2007;36:28-33.

20- Kayipmaz S, Akçay S, Sezgin ÖS. Osteoporotic mandib ular changes caused by type 2 diabetes mellitus: a comparative study by cone beam computed tomography imaging. Oral Radiol 2017;33(2):108-16.

21- Katsumata A, Hirukawa A, Okumura S, Naitoh M, Fujishita $\mathrm{M}$ et al. Relationship between density variabili ty and imaging volume size in cone-beam computerized tomographic scanning of the maxillofacial region: an in vitro study. Oral Surg Oral Med Oral Pathol Oral Radiol Endod 2009;107(3):420-5.

22- Kato CN, Tavares NPK, Barra SG, Amaral TMP, Brasile iro CB, Abreu LG, et al. Digital panoramic radiography and cone-beam $\mathrm{CT}$ as ancillary tools to detect low bone mineral density in post-menopausal women. Dentomax illofac Radiol 2019;48:20180254. 